\title{
RESTATEMENT TENTANG YURIDIKSI PERADILAN MENGADILI PERBUATAN MELAWAN HUKUM PEMERINTAH (RESTATEMENT ON JUDICIAL JURISDICTION IN ADMINISTRATIVE TORT)
}

\author{
Enrico Simanjuntak \\ Hakim Yustisial Ditjenbadilmiltun Mahkamah Agung \\ J1. Ahmad Yani No. 10, Kav. 58, Jakpus, 10510 \\ enrico_simanjuntak@yahoo.com
}

\begin{abstract}
One of the crucial problems after enactment of Government Administration Act (UUAP) concerns the extent to which the scope of court jurisdiction relating administrative torts (onrechtmatige overheidsdaad) or OOD, as intended in Article 1365 of the Civil Code. There are at least two different views on the issue. First, administrative court mutatis mutandis has power to resolve the case relating onrechtmatige overheidsdaad, this view is represented by Supreme Court Circular or Surat Edaran Mahkamah Agung (SEMA) No. 4/2016. A different view holds that the OOD act is a genus whereas the factual act as referred to UUAP is a species. This second view is not mutatis mutandis totally transferring the authority of civil judges to administrative court try the OOD case. This difference of opinion is important to be studied more thoroughly in order to know the real issue of the different views.
\end{abstract}

Keywords: Administrative court; Government Administration Act; administrative torts

\begin{abstract}
Abstrak
Salah satu persoalan krusial pasca diberlakukannya Undang-Undang Administrasi Pemerintahan (UUAP) adalah menyangkut sejauh mana implikasi perubahan yuridiksi peradilan mengadili perbuatan melawan hukum pemerintah dalam perkara OOD (onrechtmatige overheidsdaad) vide pasal 1365 KUHPerdata. Setidaknya terdapat dua pandangan sikap berbeda terkait isu tersebut. Pertama, pandangan yang menilai bahwa kini secara mutatis mutandis kewenangan Peradilan Tata Usaha Negara (Peratun) meliputi perkara-perkara OOD, sebagaimana dituangkan dalam Surat Edaran Mahkamah Agung (SEMA) No. 4/2016. Kedua, pandangan berbeda menyatakan bahwa perbuatan OOD merupakan genus sedangkan tindakan faktual dalam UUAP sebagai spesies. Konsekuensinya, tidak secara mutatis mutandis Peratun berwenang mengadili secara total perkara-perkara yang dimaksud sebagai OOD. Perbedaan pendapat ini penting untuk dikaji lebih seksama guna mengetahui permasalahan sebenarnya dari perbedaan pandangan tersebut.
\end{abstract}

Kata Kunci: Peratun; UU Administrasi Pemerintahan; Perbuatan Melawan Hukum 


\section{A. Pendahuluan}

Mengapa negara atau pemerintah dapat digugat oleh warga masyarakat tidak bisa dilepaskan dari paham ajaran negara hukum baik yang dikenal dalam paham rule of law atau rechtstaats. Ajaran negara hukum tersebut pada dasarnya mendasari pembatasan kekuasaan organ negara. Agar kekuasaan negara dapat dibatasi dan dikendalikan, maka berkembang ajaran tentang perlindungan hukum bagi warga masyarakat, beberapa pendekatannya berkembang dalam konsep hak asasi manusia, administrative justice dan lain sebagainya. Sejalan dengan itu, paham konstitusionalisme adalah paham atau aliran yang menghendaki pembatasan kekuasaan negara (limitation of state power) atau pembatasan kekuasaan pemerintahan (limited government) ${ }^{1}$.

Implementasi teori negara hukum dapat dilihat secara khas dan spesifik dari dimungkinkannya pengawasan yudisial atas tindakan pemerintah yakni melalui berbagai sarana hukum yang berkembang dalam

1 Bagir Manan. Menjaga Kemerdekaan Pers di Pusaran Hukum, Jakarta: Dewan Pers, 2010. h. 180. Tanggung-gugat pejabat pemerintahan akan terkait dengan pelaksanaan pemerintahan. Pemerintah dalam menjalankan aktivitasnya terutama dalam mewujudkan tujuan-tujuan negara melalui pembangunan (atau mengupayakan bestuurzorg) tidak berarti pemerintah dapat bertindak semena-mena, melainkan sikap tindak itu haruslah dipertanggungjawabkan. Sjachran Basah, "Perlindungan Hukum Terhadap Sikap Tindak Administrasi Negara, Orasi Ilmiah, Dies Natalis XXIX UNPAD Bandung, Tanggal 24 September 1986, h. 3. Oleh karena itu tanggung-jawab pemerintahan melahirkan tanggunggugat (liable) terhadap negara. Menurut Toshiro Fuke, yang dimaksud dengan tanggung gugat negara dalam pengertiannya yang luas adalah: "state liability means that the state should make compensation for whatever loss and or injury it has or is has deemed to have caused directly and or indirectly and materially and or mentally to citizen". Toshiro Fuke. Historical phases of State Liability as Law of Remedies-Some Introductory Remarks, dalam Yong Zhang (ed), Comperative Studies on Governmental Liability in East And Southeast Asia, Vol. 3, The Hague/London/Boston: Kluwer Law International, 1997. h. 10 berbagai model dan mekanisme yang antara lain seperti upaya administratif, judicial review, constitutional complaint, constitutional review dsb, termasuk gugatan melalui hukum perdata ${ }^{2}$. Terkait sarana pengawasan melalui hukum perdata inilah gugatan atas dasar perbuatan melawan hukum pemerintah (onrechtmatige overheidsdaad - selanjutnya disingkat OOD) sangat dikenal dalam literatur hukum sekaligus paling rendah intensitasnya ditemukan dalam praktek, terkecuali kini dalam perkara-perkara yang mengatasnamakan kepentingan publik seperti gugatan class action atau citizen law suit.

Peran hukum perdata sebagai sarana kontrol yuridis bagi pemerintah sebenarnya akan bergeser dan berangsur-angsur menepi apabila paham konstitusionalisme yang dikonkritkan dalam rezim hukum administrasi berkembang secara mapan dan signifikan dalam sistem hukum suatu negara, administrative law is concretized of constitutional law seperti ditegaskan sebuah

2 Berbagai model variasi pengawasan terhadap pemerintah terus berkembang. Dalam beberapa hal pengawasan dibedakan antara pengawasan internal dan eksternal, pengawasan posteriori dan pengawasan aposteriori. Selain itu sering dibedakan juga subyek pengawasan seperti pengawasan sosial, pengawasan politik, pengawasan publik. seiring dengan fenomena judicializiation yang semakin intens di berbagai belahan bumi. Kini dikenal sarana hukum pengaduan konstitusional (constitutional complaint). Dalil pengabaian pemerintah/negara terhadap pemenuhan kewajiban publiknya kepada warga masyarakat juga merupakan alasan pokok yang digunakan dalam perkara-perkara seperti citizen law suit atau actio popularis. Dalam ratio deciendi Majelis Hakim PN Jaksel dalam perkara No. 40/Pdt.G/2008/PN.JKT.Sel dikemukakan bahwa sifat gugatan citizen lawsuit adalah memperjuangkan kepentingan publik atau hajat hidup orang banyak dalam hal negara tidak melaksananakan kewajibannya untuk melindungi, menghormati, menegakkan dan memajukan hak-hak dan hak asasi warga negara sehingga merugikan warga negaranya sedangkan wakil-wakil dari warga negara tersebut yang duduk di lembaga negara diam atau tidak mampu memperjuangkan kepentingankepentingan atau persoalan yang merugikan warga negaranya, maka Majelis berdasarkan ketentuan mewajibkan pertanggung-jawaban negara atas kelalainya melaksanakan kewajibannya 
ungkapan hukum di Jerman. Dibandingkan dengan hukum perdata, hukum administrasi memiliki objek yang lebih spesifik, yakni fokus kepada kekuasaan pemerintahan, khususnya menyangkut relasi antara pemerintah dengan warga masyarakat (publiekrechtelijking), bukan privaatrechtelijke rechtbetreking antara pemerintah dengan warga masyarakat. Namun di Indonesia, warisan hukum perdata masih membayang-bayangi hukum administrasi.

Sejalan dengan itu, terdapat pandangan dari para hakim perdata yang cenderung menghindari gugatan terhadap pemerintah. Hal ini didasarkan kepada pandangan beberapa doktrin pada waktu itu seperti Prof. R. Sardjono yang menyatakan jika tindakan penguasa berdasarkan hukum tata negara atau hukum administrasi, maka hakim perdata tidak berwenang untuk menghukum penguasa melakukan tindakan-tindakan yang dimaksud, dalam hal itu hakim harus menyatakan gugatan tidak dapat diterima. Demikian pula pendapat Wirjono Prodjodikoro mengenai pertanggungjawaban negara atas perbuatan pemerintah dalam bukunya "Perbuatan Melanggar Hukum" menggangap tabu bagi pengadilan perdata untuk mengadili gugatan terhadap pemerintah (regeringsbeleid) "karena MPR berhak untuk mengawasi dan menegor pemerintah atas kebijaksanaannya"3

Kehadiran UU No. 30 Tahun 2014 tentang Administrasi Pemerintahan (UUAP) ${ }^{4}$ membawa implikasi perluasan kompetensi absolut Peradilan Tata Usaha Negara (Peratun). Implikasi perluasan kewenangan tersebut menimbulkan beragam penafsiran menyangkut perubahan ruang lingkup kompetensi absolut, sebagian pihak berpendapat bahwa kini hakim perdata tidak

\footnotetext{
3 A.K Ruslan, "Onrechtmatige Overheidsdaad (Perbuatan Melawan Hukum oleh Pihak Penguasa)" dalam Binacipta, Kumpulan Tulisan Hakim-Hakim Tinggi Pengadilan Tinggi Bandung Beserta Tangapan-Tanggapannya, (Bandung: PT. Rindang Mukti, 1977), hal. 70

4 Indonesia, Undang-Undang Nomor 30 Tahun 2014 Tentang Administrasi Pemerintahan, Lembaran
}

berwenang lagi mengadili perbuatan melawan hukum pemerintah, karena kini kewenangan Peratun termasuk mengadili OOD sebagaimana dimaksud oleh SEMA No. 4/2016. Namun pihak lain menilai bahwa kehadiran UUAP tidak dengan sendirinya menghapuskan kewenangan hakim perdata mengadili OOD, dengan alasan pengertian tindakan faktual dalam UUAP hanya merupakan spesies dari genus perbuatan OOD, disamping perbedaan alat uji OOD yang selama ini mengacu kepada yurisprudensi OOD sedangkan alat uji keabsahan tindakan faktual adalah peraturan perundang-undangan dan AAUPB.

\section{B. Pembahasan}

\section{Akar Sejarah Pertanggung-Jawaban Hukum Pemerintah}

Secara historis gugatan terhadap Negara c.q. pemerintah di negara-negara common law tidak bisa dilepaskan dari doktrin kekebalan kedaulatan negara (the doctrine of sovereign immunity). Pada pokoknya doktrin ini, berasal dari era kekuasaan absolut pemerintahan monarki yang menganut ajaran Raja tidak dapat berbuat salah (The King can do no wrong), sehingga dipahami kepala negara atau kepala pemerintah sebagai representasi kekuasaan tertinggi negara tidak dapat digugat oleh warga negaranya di pengadilan. $^{5}$ Dalam perkembangannya seperti di Inggris, Amerika Serikat, Jerman dan Prancis, variasi teori kedaulatan negara terkait dengan pandangan menyangkut fungsi negara dan subdivisinya, yakni pembedaan tanggung-jawab harus dibuat antara pemerintah pusat dan pemerintah daerah (badan-badan pemerintahan lokal). Alasan lain menyebutkan negara tidak dapat berbuat salah, adalah karena jika kesalahan terjadi, semata-mata karena kesalahan aparatur

Negara Republik Indonesia (LNRI) tahun 2014 Nomor 292, Tambahan Lembaran Negara Nomor 5601

5 Lihat selengkapnya George W. Pugh, "Historical Approach to the Doctrine of Sovereign Immunity", 13 La. L. Rev. (1953). Available at: http://digitalcommons.law.lsu.edu/lalrev/vol13/iss3/5 Diakses 14 Oktober 2017 
pemerintah, suatu badan yang berdaulat tidak dapat dituntut tanpa persetujuannya. Disamping itu, disebutkan bahwa harus dibedakan masing-masing antara tindakan publik dan tindakan pribadi, antara negara sebagai fiscus dan negara sebagai penguasa, antara tindakan "emanasi mahkota" dan tindakan otoritas biasa ${ }^{6}$.

Berbagai argumentasi yuridis yang berkembang pada zaman itu sehingga negara/pemerintah tidak dapat atau sulit digugat di pengadilan adalah terkait: apakah kesalahan harus menjadi dasar tanggung jawab; apakah semua kasus terhadap petugas harus dibawa ke pengadilan reguler atau ke pengadilan administratif khusus; dalam kondisi apa doktrin tuan dan pelayan atau doktrin tanggapan yang lebih tinggi harus diterapkan; perbedaan antara nonfeasance dan misfeasance; lokasi tanggung jawab untuk tindakan ultra vires, termasuk di Amerika Serikat pertanyaan pertanggungjawaban atas tindakan inkonstitusional; perbedaan antara tindakan menteri dan tindakan wajib; tanggung jawab atasan untuk tindakan inferior, dan sebagainya. Akhirnya, tanggung jawab semua unit pemerintahan harus didasarkan pada asas jaminan ${ }^{7}$.

Berakhirnya kekuatan teori kedaulatan negara digantikan oleh teori kedaulatan hukum membawa babak baru bagi pandangan negara/pemerintah untuk dapat digugat. Revolusi Prancis memberi sumbangan terbesar karena mampu membuka cakrawala baru hubungan antara warga masyarakat dengan negara/pemerintah. Sejak saat itu, sistem di

$\begin{array}{ll}6 & \text { Ibid. } \\ 7 & \text { Ibid } \\ 8 & \text { L. Neville Brown \& John S Bell, French }\end{array}$ Administrative Law, Fifth Edition, Oxford: Oxford University Press, 1998., h. 85-90

$9 \quad$ Ibid. Akhirnya dikenal secara umum bahwa tujuan utama dari hukum administrasi adalah menjaga agar kewenangan pemerintah senantiasa berada dalam batas-batas kekuasaannya (intra vires), sehingga warga masyarakat terlindung dari (potensi) penyimpangan mereka. W.R. Wade \& C.F. Forsyth, sebagaimana dikutip oleh Anna Erliyana dalam Erliyana, S., Keputusan Presiden: Analisis Keppres RI 1987-1998, Jakarta: Program Pascasarjana Fakultas Hukum Universitas Indonesia, 2005, h. 11. Dalam
Prancis, memberi dasar-dasar tumbuhnya hukum baru yakni hukum administrasi, yang membedakan dirinya dengan hukum perdata. Fundamental hukum administrasi tersebut terdiri dari prinsip pertanggung-jawaban pemerintah (administrasi) dan prinsip legalitas. Prinsip pertanggung-jawaban administrasi ini merupakan sarana penyeimbang besarnya keistimewaan (privilège) yang dimiliki administrasi pemerintahan yang tercermin antara lain dalam kekuasaan untuk melaksanakan keputusan (décision exécutoire) yang melahirkan hak dan kewajiban secara unilateral yang akan mengikat pihak ketiga (warga masyarakat) tanpa persetujuan mereka ${ }^{8}$. Keistimewaan kedua adalah adanya kekhususan yuridiksi (privilège de juridiction) yakni berkaitan kedudukan pengadilan administrasi untuk mengadili keputusan/tindakan administrasi dalam sistem peradilan tersendiri, diluar yuridiksi Peradilan Umum (ordinary courts). Kekuasaan Peradilan Umum sesuai ajaran pemisahan kekuasaan tidak berwenang mengadili legalitas keputusan/tindakan administrasi. Kewenangan Peradilan Administrasi di Prancis selain mengadili legalitas tindakan/keputusan administrasi juga berwenang mengadili tuntutan ganti rugi terhadap pemerintah oleh warga masyarakat ${ }^{9}$.

Lebih lanjut, istilah responsabilité dalam hukum Prancis harus dilihat tanpa mengakualifikasikan tanggung-jawab delik dan quasi delik, artinya pertanggungjawaban pemerintah/administrasi tidak terkait apakah perbuatan yang

sistem hukum common law dikenal doktrin ultra vires, dimana berdasarkan doktrin ini, tindakan administrasi yang tidak sesuai dengan ketentuan peraturan yang mendasarinya, akan dinyatakan ultra vires. Konsekuensi hukum atas tindakan hukum yang dinyatakan ultra vires akan batal demi hukum (null and void) dan dianggap tak pernah ada. Sebagaimana dikemukakan oleh Neil Hawke \& Neil Parpworth: "Where it is found that an administrative agency has acted outside or beyond its statutory powers, any resulting decision or other act may be recognised as ultra vires, that is, null and void so that in law it has never existed". Neil Hawke \& Neil Parpworth, Introduction To Administrative Law, London: Cavendish Publishing Limited, 1995, h. 1. 
membahayakan dan perbuatan yang tidak dimaksudkan menimbulkan kerugian yang berasal dari kelalaian (negligence) atau tindakan atau kondisi yang rentan beresiko (risk). Keduanya saling berkorespondensi secara luas dan meliputi bidang torts sebagaimana dimaksudkan dalam hukum Inggris. Sehingga di Prancis, administrasi dapat liable dalam situasi tertentu tanpa adanya suatu kesalahan, manakala kerugian (harm) dialami oleh individu dalam rangka kepentingan publik (public good). Oleh karena itu, beberapa penulis berpendapat tanggung-jawab administrasi (administrative liability) tidak harus didasarkan adanya perbuatan yang merugikan orang lain (sebagaimana dimaksud Pasal 4 Deklarasi Hak-Hak Manusia tahun 1789) namun berdasarkan prinsip 'kesetaraan atas beban publik' (equality before public burdens; égalitè devant les charges publiques) sebagaimana dinyatakan dalam Pasal 13 Deklarasi tersebut ${ }^{10}$. Sedangkan, istilah kesalahan (torts) dalam konteks hukum administrasi Prancis merupakan sebuah konsep yang terbuka dan merupakan prinsip umum, sebagaimana konsep égalitè devant les charges publiques, yang pengertiannya mengacu kepada situasi tertentu namun batasan defenisinya bersifat fleksibel disesuaikan dengan permasalahanpermasalahan baru yang berkembang. Oleh karena itu, ketika seorang bocah berumur 15 tahun mengalami paraplegia sebagai akibat teknik pembedahan baru di rumah sakit pemerintah, dia mendapat kompensasi kerugian tanpa harus membuktikan adanya kelalaian medis (medical negligence), dengan dasar resiko teknik bedah baru yang sama sekali tidak diketahui memiliki efeksamping (Putusan Conseil d'Etat 3 November 1997 dalam perkara Hôpital Joseph-Imbert D'arles). Dalam putusan landmark Blanco, Tribunal des Conflicts menyatakan: "negara bertanggung-jawab namun tidak dapat dikenakan pertanggung-

10 Ibid. jawaban mutlak sebagaimana individu subyek perdata".

Sedangkan sistem penyelesaian sengketa antara warga masyarakat dengan pemerintah di Belanda berbeda dengan sistem di negaranegara common law dengan model unity of jurisdiction atau sistem di Prancis dengan konsepsi dual-jurisdiction-yang menjadi model rujukan bagi sebagian besar sistem penyelesaian sengketa administrasi dalam tradisi hukum civil law termasuk di Indonesia, yakni pasca berlakunya UUAP. Sistem penyelesaian sengketa administrasi di Belanda berkembang melalui karakteristik tersendiri, berdasarkan konsolidasi pembagian peran antara badan peradilan (in casu pengadilan negeri melalui kamar sengketa administrasi) dengan badan Peradilan Administrasi semu (organ kuasi yudisial). Kombinasi antara penyelesaian yudisial dengan upaya administratif sebagaimana terlihat dalam sistem Belanda ini mencerminkan kuatnya akar warisan hukum berusia ratusan yakni sarana upaya administratif (internal review) sekaligus usaha untuk menerima dinamika perkembangan modernisasi yang tercermin dalam sarana judicial review. Konsekuensinya, tidak seperti di Prancis, Belanda dalam skala tertentu masih merujuk kitab hukum perdata warisan Napoleon untuk menjaring hal-hal yang tidak diatur dalam Algemene wet bestuurecht ( $A w b)$ - semacam UUAP jika dipadankan kini di Indonesia. Dalam sistem di Belanda, kewenangan Peradilan Biasa (hakim perdata) mengadili perbuatan melawan hukum pemerintah adalah bersifat residual dari kewenangan orisinal 'hakim administrasi' yang hanya berwenang mengadili keputusan yang bersifat individual, tidak termasuk keputusan yang bersifat umum atau tindakan-tindakan riil dalam rangka pelaksanaan bestuurdwang. ${ }^{11}$ Sistem di Belanda tidak pernah secara formal mengenal kekuasaan peradilan administrasi yang terpisah dari kekuasaan peradilan umum. Sistem di

11 Seerden, René \& Frits Stroink. Op. Cit., hal. 208209 
Belanda yang berlaku sekarang persis seperti sistem hukum yang berlaku sebelum Indonesia mengenal Peratun.

Sebelum lahir Peratun sebagai suatu lingkungan Peradilan tersendiri dalam sistem hukum di Indonesia, dikaitkan dengan pasal $2 \mathrm{RO}$, praktis gugatan terhadap pemerintah diadili berdasarkan ketentuan pasal 1365 KUHPer. Bahkan ketika Peratun sudah berdiri pun, keterbatasan ruang lingkup objek sengketa TUN dalam UU Peratun, membuat ketentuan pasal 1365 KUHPer masih terus digunakan sebagai dasar hukum menggugat pemerintah, menggugat hal-hal yang tidak terjangkau oleh UU Peratun. Ketentuan 1365 KUHPer ibarat pasal 'sapu jagad', senantiasa digunakan untuk menjaring perbuatanperbuatan yang dianggap merugikan kepada warga masyarakat, jika tidak diatur khusus oleh peraturan hukum sektoral. Namun persoalannya menjadi lain ketika kini kewenangan Peratun tidak hanya berdasarkan UU Peratun, kehadiran UUAP memperluas kewenangan Peratun, dan persoalannya sebagaimana topik tulisan ini adalah seberapa luas implikasi UUAP mengurangi kewenangan hakim perdata dalam menggunakan pasal 1365 KUHPer $^{12}$. Pertanyaan akhirnya adalah apakah sistem perlindungan hukum administrasi di Indonesia kini konsisten dengan rezim duality of jurisdiction yang khas hukum Prancis, yang berdasarkan pendekatan sistem tidak mengenal kekuasaan residual hakim perdata dalam sengketa administrasi.

\section{Problematik Hukum Perdata Sebagai Sarana Kontrol Hukum Terhadap Pemerintah.}

Ruang lingkup pengertian perbuatan melawan hukum pemerintah di Indonesia berasal dari perbuatan melawan hukum dalam kitab hukum perdata di Belanda. Akar sejarah pengertian perbuatan melawan

12 Meskipun secara statistik perkara OOD jumlahnya tidak banyak atau jarang diajukan namun secara esensi perkara jenis ini sesungguhnya ibarat perkara pukat harimau karena ruang lingkup permasalahan hukum yang dapat dikategorikan objek perkara jenis sangat banyak dan bervariasi. hukum di Belanda berasal dari code civil warisan Prancis. Rumusan perbuatan melawan hukum dalam ketentuan 6:162 Perdata Belanda yang pararel dengan Pasal 1365 KUHPerdt di Indonesia berasal dari artikel 1382, 1383, 1384 Code Civil Perancis dari Code Napoleon. Ironisnya, ajaran perbuatan melawan hukum pemerintah di Prancis sudah sekian ratus tahun tidak mengadopsi kitab hukum perdata karena mereka mengembangkan konsep administrative torts diluar kaidah code civil. Kitab perdata Belanda pun terus mengalami pembaharuan, sedangkan Indonesia masih mengacu pada kitab perdata yang lama. Rumusan perbuatan melawan hukum dalam kitab perdata di Belanda sudah berkembang sangat luas, berbeda dengan pasal 1365 KUHPer Indonesia. Pada pokoknya rumusan perbuatan melawan hukum dalam kitab Perdata Belanda sekarang sebagaimana dimaksud Pasal 6:162 Perdata Belanda ${ }^{13}$ adalah terdiri dari: (a) pelanggaran atas hak; (b) pelanggaran atas suatu kewajiban hukum; (c) pelanggaran terhadap aturan hukum tidak tertulis tentang perilaku sosial yang tepat.

Secara substansi, konsep atau istilah "Perbuatan Melawan Hukum" dalam pasal 1365 KUHPer lebih merupakan sebagai suatu konsep hukum umum (general law concept) dibandingkan sebagai sebuah defenisi normatif kaidah hukum. Dalam hal itu, makna 'perbuatan melawan hukum' dalam rumusan pasal 1365 KUHPer tersebut merupakan kaidah yang sebenarnya mengacu kepada ajaran hukum yang berlaku universal (natural rights) yakni bahwa setiap subyek hukum yang melakukan perbuatan hukum dan menimbulkan kerugian bagi pihak lain harus mempertanggung-jawabkan perbuatannya kepada pihak yang dirugikan, baik subyek hukum itu manusia (natuurlijk persoon), badan hukum (rechtspersoon), maupun jabatan (ambt). Dengan kata lain,

13 Hans Nieuwenhuis, dalam Rosa Agustina dkk, Perbuatan Melawan Hukum, Jakarta: Program Pasca Sarjana Fakultas Hukum Universitas Indonesia, 2003, h. 26. . 
rumusan pasal 1365 merupakan doktrinal hukum umum.

Sejalan dengan hal ini, Rosa Agustina ${ }^{14}$ menyatakan bahwa pengertian perbuatan melawan hukum dalam pasal 1365 KUHPer merupakan rumusan yang sangat terbuka untuk dikembangkan (open-ended), karena pasal itu merupakan kerangka normatif. Menurutnya perumusan yang demikian akan memberikan keleluasaan pada hakim untuk menemukan hukum. Meskipun kini terdapat beberapa undang-undang yang secara sektoral mengatur perbuatan melawan hukum, bagi Rosa Agustina termasuk UU Peratun, tetapi ketentuan-ketentuan itu tidak perlu menggantikan rumusan normatif pasal 1365 KUHPer. Sebab pasal 1365 KUHPer pada saat yang sama dapat dikatakan merupakan ketentuan yang bersifat genus terhadap ketentuan-ketentuan yang lain yang juga mengatur mengenai perbuatan melawan hukum secara lebih khusus. ${ }^{15}$

Perumusan kaidah hukum yang terlalu luas dan umum akan rentan menimbulkan ketidakpastian hukum. Hal ini terbukti dalam praktek penerapan pasal 1365 untuk digunakan menggugat pemerintah/negara. Disamping itu, setidaknya terdapat 2 (dua) alasan pokok mengapa penggunaan ketentuan pasal tersebut menjadi problematis untuk digunakan dalam kondisi sekarang sebagai dasar menggugat perbuatan melawan hukum pemerintah. Beberapa alasannya adalah sbb:

\section{a. Over-generalisasi Sifat Melawan \\ Hukum Ketentuan Pasal 1365.}

Semakin spesifik rumusan suatu norma, maka semakin jelas kriteria sasaran perbuatan hukum maupun subyek hukum yang diatur. Demikian pula sebaliknya. Inilah salah satu penjelasan mengapa kaidah pasal 1365 KUHPer mampu ditafsirkan secara luas

14 Rosa Agustina. Perbuatan Melawan Hukum, Jakarta: Program Pasca Sarjana Fakultas Hukum Universitas Indonesia, 2003. h. 242-243.

15 Ibid.

16 Frank J. van Ommeren, "Governance and the Public-Private Law Divide in the Netherlands", p. 5. http://dare.ubvu.vu.nl/handle/1871/41255?show=full, Cambridge Law Journal, diakses 12 Oktober 2014. dalam berbagai peristiwa hukum yang berkaitan dengannya. Dalam beberapa hal mengandung irisan (legal grey area) dengan ruang lingkup pengertian melawan hukum secara pidana (wederrechtelijkheid), "delictenrecht" dalam hukum adat, dan terutama dengan konsepsi legalitas perbuatan administrasi, dengan atau tanpa maladministrasi dalam ranah hukum administrasi.

Dalam doktrin hukum umum (general law doctrine) sebagaimana dikemukakan Frank J. van Ommeren ${ }^{16}$, hukum administrasi secara fundamental dipandang tidak berbeda dengan hukum perdata. Sehingga dalam pandangan ini, terlepas dari ada tidak adanya perbedaan, hukum perdata merupakan bagian dari hukum umum dan hukum administrasi adalah hukum khusus. Konsekuensinya, hukum perdata dapat bekerja sepanjang kaidah hukum administrasi tidak ada mengatur sebaliknya. Refleksi pendapat seperti ini terlihat dari praktek yang berlaku sekarang di negara Belanda, Jerman dsb. Artinya, keberlakuan ajaran onrechtmatige overheisdaad hanya berlaku sepanjang perbuatan melawan hukum administrasi (administrative torts) tidak dikenal sebagai suatu rezim hukum positif.

Catatan berbagai ahli hukum seperti Kranenburg, Oemar Seno Haji, Sudikno Mertokusomo menunjukan bahwa dalam praktek, over-generalisasi pengertian perbuatan melawan hukum menimbulkan inkonsistensi dan ketidakpastian hukum di masa lalu baik di negeri Belanda maupun di Hindia-Belanda atau di Indonesia pasca kemerdekaan, dengan asas konkordansi menerapkan pasal 1365 KUHPer $^{17}$. Kondisi ini menurut Sudikno tidak terlepas dari sulitnya menentukan batasan kebebasan

\footnotetext{
17 Kranenburg, Perkembangan Peradilan Tentang Pertanggungan-Jawan Negara, judul asli 'de ontwikkeling der reschtspraak betreffnde de staatsaansprakelijkheid', diterjemahkan ole R.H. Kasman Singodimejo dan Mohamad Saleh, Jakarta: Penerbit Permata, 1973. Sudikno Mertokusomo. Op. Cit. Ali, C. Yurisprudensi Indonesia Tentang Perbuatan Melawan Hukum oleh Penguasa, Bandung: Binacipta, 1978, h. 15-19
} 
bertindak pemerintah dikaitkan dengan kebutuhan perlindungan hukum masyarakat. Ketidakjelasan seperti ini dikaitkan dengan sifat umum dari rumusan perbuatan melawan hukum, sehingga setiap peristiwa harus dilihat secara kasuistis, dilihat secara sendirisendiri. ${ }^{18}$

\section{b. Ketidakjelasan pertanggung-jawaban pribadi atau jabatan.}

Sebagaimana telah dikemukakan sebelumnya di atas kaidah pasal 1365 KUHPer tidak membedakan apakah pelaku perbuatan melawan hukum subyek hukum manusia atau badan hukum perdata, apakah pelanggaran dalam lapangan hukum perdata atau hukum publik ${ }^{19}$. Dalam sudut pandang pasal 1365 KUHPer ini, pemerintah selaku pihak tergugat diposisikan sebagai badan hukum perdata, dan direpresentasikan oleh masing-masing pejabat puncak organisasi seperti : Presiden, Gubernur, Bupati/Walikota dan seterusnya. Oleh karena pejabat puncak tersebut sekadar representasi organisasi, hubungan hukum antara pejabat yang digugat dengan peristiwa hukum yang dipersoalkan sering tidak jelas atau memiliki korelasi. Misalnya ketika Presiden digugat dalam kasus penyelenggaraan ujian nasional, hubungan Presiden dengan penyelenggaraan ujian nasional adalah semata-mata karena

18 Sudikno Mertokusomo, Ibid. h. 72

19 Pada awal mula perkembangannya, Mahkamah Agung Belanda (Hoge Raad) berpendirian bahwa sifat melanggar hukum perbuatan pemerintah hanya dapat dinilai menurut hukum publik dan tidak dapat dinilai menurut ukuran hukum perdata. Artinya, dalam menjalankan kewajiban hukumnya, pemerintah tidak bisa dinilai telah melanggar hak subyektif orang lain. Putusan seperti ini tercermin dalam putusan Hoge Raad tanggal 21 April1898 dalam perkara Rhendense Koe. Dalam perkara ini seekor sapi lepas dari kandangnya, lalu karena sapi itu mengamuk di jalan atas perintah walikota Rheden, sapi tersebut ditembak, dibakar dan dikuburkan. Si pemilik sapi diberi uang f.2.43 sebagai ganti rugi namun ia menolak dan menggugat walikota ke pengadilan. Tetapi kemudian pengadilan menolak gugatan si pemilik sapi dengan alasan walikota dalam kasus tsb adalah sedang menjalankan kewajiban hukumnya. Perkara Osterman (20 Nopember 1924) menandai perubahan sikap peradilan di Belanda yang menilai pelanggaran hukum pemerintah tidak hanya dapat dinilai berdasarkan kaidah hukum publik. Sejak putusan Osterman tsb,
Menteri Pendidikan, yang bertanggungjawab langsung dalam masalah urusan penyelengaraan pendidikan, bertanggungjawab kepada Presiden. Jika ditelisik lebih jauh unsur-unsur pasal 1365 yang terdiri dari : (a) perbuatan (daad); (b) kesalahan (schuld); (c) kerugian (schade); (d) hubungan sebab-akibat (causalitet), sering mengandung kontradiksi dalam praktek penerapan kaidah OOD. Seperti dalam kasus ujian nasional tersebut di atas, unsur kesalahan dari subyek hukum Presiden tidak jelas, tidak spesifik, sehingga unsur hubungan sebab-akibat dari pasal tersebut pun tidak terpenuhi atau sulit untuk diterapkan.

Hal ini tidak bisa dilepaskan dari ketidakmampuan pasal 1365, mengindentifikasi secara spesifik hubungan antara subyek hukum yang digugat dengan peristiwa hukum yang dipersoalkan. Sederhananya, pasal 1365 KUHPer tidak melihat syarat "siapa berbuat, dia bertanggung-jawab”, sebagaimana dikenal dalam hukum publik. Ketentuan pasal 1365 KUHPer seolah-olah menggunakan logika pertanggung-jawaban mutlak (strict liability) atau pertanggung-jawaban pengganti (vicarious liability), fokus menyasar subyek hukum yang merepresentasikan kedudukan

perbuatan pemerintah yang melanggar hak subyektif orang lain dianggap juga sebagai perbuatan melanggar hukum. Dalam perkara Baron van der Verwolde (Hoge Raad 9 Mei 1902) terdapat dua pertimbangan hukum: (1) Negara dan alat perlengkapannya, selaku penguasa, juga dapat melakukan perbuatan melanggar hukum dan dapat dipertanggung-jawabkan menurut hukum terhadap perbuatan-perbuatannya; (2) Pasal 2 RO tidak membedakan pembatasan sengketa keperdataan antara bijzondere personen sehingga semua sengketa tentang hak milik dan hak-hak yang timbul daripadanya menjadi kewenangan kekuasaan kehakiman, termasuk dengan penguasa yang timbul karena pelanggaran hak subjektif orang lain. Baron van der Borch van Verwolde mengajukan gugatan karena pihak kotamadya membuat saluran air tepat di atas balok penyangga (fondasi) rumahnya. Setiawan, Contoh-Contoh Kasus Perbuatan Melanggar Hukum Oleh Penguasa Perkembangannya Dalam Yurisprudensi di Negeri Belanda, dalam P.J.J. Sipayung (ed), Pejabat Sebagai Calon Tergugat dalam Peradilan Tata Usaha Negara, Buku Kedua, Jakarta: C.V. Sri Rahayu, 1989. h. 102-106 
suatu badan hukum perdata, sehingga organisasi publik sekompleks pemerintah pun hanya dipandang dari sudut antara kuasa dan prinsipal organisasi. Sementara dalam aturan hukum publik, tindakan hukum organisasi pemerintah dilakukan oleh pejabat yang berwenang. Dalam konsep hukum publik, pertanggung-jawaban hukum itu berkaitan erat dengan pengunaan kewenangan, yang kemudian melahirkan prinsip "geen bevoegdheid zonder verantwoor-delijkheid, there is no authority without responsibility", yakni tidak ada kewenangan tanpa pertanggung-jawaban. ${ }^{20}$ Belifante menyatakan: "Niemand kan bevoegheid uitoefenen zonder verantwoording schuldig te zijn of zonder dat op die uitoefening controle bestaan" (Tiada seorang pun dapat melakukan kewenangan tanpa memikul kewajiban tanggung-jawab atau tanpa ada pelaksanaan pengawasan $)^{21}$.

Oleh karena basis tindakan administrasi pemerintahan adalah kewenangan (baik kewenangan terikat atau kewenangan diskresioner) maka sesuai asas legalitas, identifikasi pertangggung-jawaban

20 Ridwan, Tiga Dimensi Hukum Administrasi Negara dan Peradilan Administrasi Negara, Yogyakarta: FH UII Press, 2009, h. 51. Lihat juga Yos Johan Utama, "Membangun Peradilan TUN yang Berwibawa”, Disampaikan pada Upacara Penerimaan Jabatan Guru Besar Dalam Ilmu Hukum pada Fakultas Hukum Universitas Diponegoro Semarang, 4 Februari 2010, h. 41

21 Ridwan HR, Hukum Administrasi Negara, Jakarta: Rajawali Pers, 2011, h. 352.

22 Dalam kasus tersebut, Agnes Blanco tertabrak oleh truk yang sedang melintas jalanan pada kawasan pabrik tembakau milik negara di kawasan Bordeaux, Tribunal des Conflicts pada tahun 1873 menetapkan tiga prinsip. Pertama, negara bertanggung-jawab atas kesalahan para pegawainya. Kedua, pertanggungjawaban administrasi berbeda dengan pertanggungjawaban sebagaimana dimaksud kitab hukum perdata dan ketiga pertanggung-jawaban administrasi merupakan kompetensi absolut Peradilan Administrasi. Dalam perkara Feutry (Tribunal Court 29 Februari 1908) prinsip pertanggung-jawaban umum sebagaimana ditetapkan dalam kasus Blanco tidak diterapkan lagi kepada semua otoritas publik. Dalam kasus ini seorang yang mengalami gangguan kejiwaan melarikan diri dari rumah sakit yang dikelola oleh sebuah departemen kemudian membakar rumah milik Penggugat, departemen bertanggung-jawab atas hukum para pengemban kewenangan itu pun harus memperhatikan differensiasi kewenangan, yakni kewenangan atribusi, delegasi dan mandat. Impelementasi ketiga jenis kewenangan tersebut memiliki perbedaan tanggung-gugat dalam ajaran hukum administrasi sedangkan dalam pengujian OOD berlaku sebaliknya, sehingga sangat lazim dalam perkara perbuatan melawan hukum misalnya terhadap Kepala Kantor Pertanahan di Kabupaten X, namun Kepala BPN di pusat dimasukan sebagai Turut Tergugat atas kesalahan kedinasan dari pejabat lain yang berada jauh di bawah hirarki strukturalnya. Parameter kewenangan menjadi dasar dan syarat pertanggungjawaban hukum publik, maka dalam hukum publik, dimana hukum perdata tidak mengenalnya, dibedakan pertanggungjawaban jabatan (institusi) dan pertanggungjawaban pribadi dari si pejabat. Ajaran hukum publik ini bersumber dari hukum administrasi Prancis, dalam putusan Blanco (Blanco Arrest) yang dikenal sebagai landmark decision ${ }^{22}$.

ganti rugi. Dikatakan sebagai faute personnelle apabila terdapat kesalahan personal dalam sebagian pelayanan, yakni, sebuah kesalahan 'tidak dikaitkan dengan pelayanan publik namun mengungkapkan kelemahan, sikap, ketidakcermatan'. Ketika kesalahan personal terjadi, pegawai dapat dituntut di Peradilan Umum. Sebaliknya, manakala terjadi kesalahan dinas (a faute de service), pegawai memiliki kekebalan dengan alasan prinsip pemisahan kekuasaan yang melarang Peradilan Umum mengadili tindakan administrasi. Dengan demikian, pihak yang dirugikan harus menggugat di pengadilan administrasi. Baik faute personnelle dan faute de service dapat bersifat kumulatif (cumul). Putusan Conseil d'Etat tgl. 3 Februari 1911 menyatakan dua kesalahan dalam suatu peristiwa penyerangan pengunjung kantor pos oleh pegawai kantor pos. Penyerangan terjadi karena pengujung memasuki kantor pos yang sudah sudah ditutup secara prematur. Penutupan kantor pos secara prematur merupakan faute de service sedangkan penyerangan oleh pegawai kantor pos merupakan faute personnelle. Conseil d'Etat menyatakan negara bertanggung-jawab atas penutupan secara prematur sedangkan atas penyerangan yang terjadi diluar tanggung-jawab negara. Namun meskipun terdapat dua kesalahan bukan berarti doktrin cumul membenarkan korban mendapatkan kompensasi dua kali, yakni menggugat di Peradilan Administrasi atau 
Sebelum tahun 1919, OOD dimaknai sebagai sebagai onwetmatige daad sehingga sumber hukum satu-satunya adalah undangundang. ${ }^{23}$ Sesudah tanggal 31 Januari 1919, Hoge Raad dalam perkara Lindenbaum dan Cohen menafsirkan secara luas pengertian pasal $1365 \mathrm{BW}$ yang berbunyi:

"Een onrechtmatige daad is een hendelen of natalen, dat of inbreuk maakt op eens anders recht, of in strijd is met des daders recht plict, of indruist, hetzy tegen de goede zeden, hetzy tegen de zorgvuldigheid, walke in het maatschappelyk verkeer betaamt ten aazien van eens anders persoon of goed (suatu perbuatan melawan hukum ialah suatu perbuatan atas kelalaian yang melawan hak-hak orang lain, atau bertentangan dengan kewajiban hukum sendiri, atau berlawanan dengan kesusilaan yang baik, atau sikap berhati-hati yang selayaknya dalam pergaulan masyarakat

di peradilan biasa. Dalam kasus-kasus cumul seperti ini, Conseil d'Etat pada akhirnya membebankan ganti rugi melalui Peradilan Administrasi. Doktrin faute personnelle dan faute de service digunakan untuk menentukan besaran ganti rugi kolektif yang dihitung berdasarkan beban pertanggung-jawaban pribadi dan beban pertanggung-jawaban jabatan (institusional). Dalam konsepsi perbuatan melawan hukum administrasi (adminstrative torts) di Prancis juga dibedakan dua derajat kesalahan yakni kesalahan sederhana (simple fault, faute simple) yang dapat diartikan sebagai jenis kesalahan yang mudah diidentifikasi dan 'kesalahan kotor' (gross fault, faute lourde). Gross fault adalah kesalahan yang tidak mudah untuk diukur, diterapkan dalam kasus-kasus pelayanan publik yang bersifat kompleks dan sensitif, seperti menyangkut pelaksanaan diskresi kepolisian, pajak dan beberapa kasus dalam regulatory controls. ${ }^{22}$ Terkait namun tidak hanya terbatas dengan konsep simple fault (faute simple) dan gross fault (faute lourde), sejak tahun 1944, Conseil d'Etat membangun prinsip umum mengenai tanggung-jawab tanpa terhadap pribadi atau benda orang lain $)^{24}$.

Prof. Oemar Seno Adji dalam kapasitas sebagai Ketua MA pernah mengeluarkan surat edaran terkait perbuatan melanggar hukum penguasa. Salah satu point dalam surat edaran tersebut menyinggung bahwa perumusan pengertian OOD dalam yurisprundensi Indonesia terhenti dalam perumusan Ostermann Arrest tanggal 20 Nopember 1924. Dijelaskan lebih lanjut dalam surat tersebut bahwa 4 (empat) unsur pengertian perbuatan melawan hukum sesudah tahun 1919 yakni : 1) Pelanggaran terhadap hak subyektif dari orang lain; 2) Bertentangan dengan kewajiban hukum sendiri; 3) Bertentangan dengan kesusilaan yang baik; 4) Bertentangan dengan kepatutan yang ada dalam masyarakat. Unsur terakhir yakni unsur bertentangan dengan kesusilaan yang baik dan bertentangan dengan kepatutan yang ada dalam masyarakat, menurut Prof. Oemar Seno Adji, dengan merujuk putusan Strooppot, adalah tidak dapat diterapkan terhadap perbuatan-perbuatan yang dilakukan oleh penguasa/pemerintah. Dicontohkan olehnya bahwa putusan MA No. 838 K/Sip/1970 yang senafas dengan Ostermann Arrest diangap terlalu menekankan perlindungan individu terhadap

kesalahan (liability without fault) berdasarkan teori resiko (theory of risk). Aktivitas pemerintahan, meskipun dilaksanakan tanpa adanya kesalahan, dalam beberapa situasi kerap mengandung resiko; jika resiko bersifat material dan individual yang menyebabkan kerugian atau potensi kerugian, negara wajib memberikan ganti rugi. Prinsip ini berkaitan dengan égalitè devant les charges publiques yang tertera dalam Pasal 13 Deklarasi Hak Asasi Manusia Prancis. L. Neville Brown \& John S Bell. Loc. Cit. h. 181-182

23 T. Boestomi, "Onrectmatige Overheidsdaad (Perbuatan Melawan Hukum Oleh Pihak Penguasa) Sebagai Dasar Pengaduan dan Gugatan Ganti Rugi”, dalam Binacipta, Kumpulan Tulisan Hakim-Hakim Tinggi Pengadilan Tinggi Bandung Beserta Tangapan-Tanggapannya, (Bandung: PT. Rindang Mukti, 1977) hal. 44

${ }^{24}$ Ibid 
penguasa, sehingga kurang sesuai dengan alam pikiran Indonesia yang hendak mengadakan keseimbangan antara perlindungan terhadap perseorangan (individu) dan terhadap 'kepentingan persekutuan seperti penguasa' sehingga yurisprudensi tersebut harus disempurnakan. MA menyarankan agar tidak hanya melihat pada perbuatan materil (tindakan faktual) yang dilakukan pemerintah tetapi terutama juga harus melihat keadaan dimana perbuatan tersebut terjadi, mempunyai sifat hukum publik tertentu ${ }^{25}$. Kriteria pelanggaran hukum seperti ini sebelumnya dikritik oleh Kranenburg. Kranenburg menilai tolak ukur penilaian pengadilan, dalam hal ini putusanputusan Hoge Raad, cenderung berdasarkan sifat hak yang telah dilanggar oleh perbuatan itu, bukan berdasarkan sifat perbuatan yang dilakukan (maksudnya apakah berdasarkan hukum publik atau hukum perdata)

Persolaan berikutnya dibalik pengunaan kriteria hukum tersebut di atas adalah penggunaan keempat unsur tadi apakah bersifat kumulatif atau alternatif. Sifat kumulatif artinya jika satu unsur saja tidak terpenuhi dari keempat kriteria OOD tidak terpenuhi, maka dengan sendirinya OOD tidak terpenuhi. Sebaliknya, terdapat pandangan lain yang menilai bahwa keempat unsur tadi tidak harus terpenuhi secara kumulatif. Terdapat pandangan yang menilai bahwa unsur "kesalahan" (schuld) bukanlah unsur utama dalam terpenuhinya perbuatan melawan hukum, melainkan bagaimana memulihkan kerugian (restitiu in integrum) suatu keadaan yang diakibatkan oleh kesalahan, artinya yang utama apakah terjadi

25 Surat Edaran Ketua Mahkamah Agung No. M.A./Pemb/0159/77 Tanggal 25 Februari 1977. Ali, C., Op. Cit. h. 15-19.

26 Hal ini tidak terlepas dari sepak terjang Conseil d'Etat mengembangkan dua prinsip utama yakni legalitas (légalité). Ini artinya setiap tindakan administrasi harus berdasarkan hukum jika tidak keputusannya akan dibatalkan oleh pengadilan administrasi. Dalam bahasa Dicey prinsip ini menjamin administrasi mematuhi Rule of Law. Sejalan dengan hal ini, prinsip ini menjadi justifikasi bagi para ahli hukum konstitusi Prancis untuk menggambarkan Etat de droit, negara berdasarkan hukum, kerugian kepada penggugat atau tidak. Jika pandangan seperti ini diterima sepenuhnya menjadi kontradiktif istilah perbuatan melawan hukum karena unsur kesalahan yang merupakan dasar ada tidaknya perbuatan melawan hukum tidak terpenuhi. Pandangan kedua ini berbeda dengan pandangan sebelumnya yang bersifat konvensional yang selalu menyaratkan adanya kesalahan (schuld, fault) serta hubungan kausalitas antara kesalahan dengan kerugian (schade, damage). Pandangan kedua ini, identik dengan prinsip responsabiliie de l'administration dalam hukum publik, artinya dalam prinsip pertanggung-jawaban pemerintah dalam hukum administrasi, pemerintah senantiasa wajib bertanggung-jawab atas tindakannya yang merugikan (maupun tidak merugikan) rakyat, meskipun pemerintah tidak melakukan kesalahan hukum ${ }^{26}$.

\section{Kewenangan Peratun Dalam Mengadili Perbuatan Melawan Hukum Pemerintah}

Pasca berlakunya UUAP telah terjadi ledakan besar (big bang) seiring dengan perubahan pemaknaan keputusan sebagai objek sengketa TUN. Dani Elfah ${ }^{27}$ menyatakan bahwa konsep keputusan di dalam Pasal 1 angka 7 UUAP telah mendekonstruksi atau sebagaimana ia istilahkan telah 'menjungkirbalikkan' konsep KTUN sebagaimana dimaksud selama ini dalam Pasal 1 angka 9 UU Peratun. Objek sengketa TUN kini tidak sebatas keputusan berkarakter konkrit, individual, akan tetapi multi karakter yaitu abstrak - individual, dan

sebagaimana dapat dibandingkan dengan negara di atas hukum atau Etat de police. Prinsip kedua adalah pertanggung-jawaban (responsabilité). Prinsip ini menunjukan bahwa administrasi akan bertanggungjawab (responsible) memberikan kompensasi bagi pihak yang dirugikan oleh keputusan atau tindakan administrasi, yang mungkin tidak sah dalam semua peristiwa. L. Neville Brown \& John S Bell. Op. Cit. h. 181-182

27 Dani Elfah, "Keputusan dan Tindakan Administrasi Pemerintahan", Makalah Tidak Diterbitkan, h. 54 
konkrit umum ${ }^{28}$. Melalui Pasal 1 angka 7 UUAP telah menjadikan sistem Peratun yang semula Peratun super khusus telah bergeser menjadi sistem Peratun yang dapat memeriksa dan menguji semua tindakan Badan dan/atau Pejabat Pemerintah termasuk tindakan konkret/faktual-abstrak individual, dan umum konkrit ${ }^{29}$. Sejalan dengan itu, MA menegaskan bahwa konsekuensi kehadiran UUAP membawa perubahan paradigma beracara di Peratun sebagaimana ditegaskan oleh kebijakan MA pasca berlakunya UUAP, kini kompetensi Peratun meliputi: (a) perkara berupa gugatan dan permohonan; (b) perkara perbuatan melawan hukum oleh pemerintah, yang biasa dikenal sebagai OOD; (c) perkara yang sebelumnya telah diperiksa dan diputus melalui upaya banding administrasi menjadi kewenangan PTUN ${ }^{30}$.

Namun kiranya perlu dilihat beberapa hal secara lebih seksama. Pertama, perlu dipahami bahwa pengertian perbuatan (daad, action) dalam pasal 1365 adalah mengandung makna ganda yakni baik berbuat (action) atau tidak berbuat (inaction). Dengan kata lain pengertian daad dalam pasal 1365 ini pararel dengan pengertian perbuatan melawan hukum (torts) dalam sistem common law yang mencakup pengertian antara berbuat dan tidak berbuat (action and inaction). Perbuatan dapat berarti tindakan konkrit (tindakan faktual) seperti menertibkan bangunan liar oleh Satpol PP. Perbuatan dapat berarti melakukan sesuatu sebagaimana apa yang menjadi kewenangannya dalam konteks penyelenggaraan urusan pemerintahan: penyusunan kebijakan, pembuatan peraturan, pembuatan keputusan dll. Tidak berbuat dapat mengandung beragam makna antara lain pengabaian kewajiban hukum, tidak melaksanakan sesuatu dsb. Kesulitan menentukan apakah dengan sendirinya hakim perdata tidak berwenang lagi

\footnotetext{
28 Ibid, h. 56

29 Ibid.

30 SEMA No. 4 Tahun 2016 Tentang Pemberlakuan Rumusan Hasil Rapat Pleno Kamar Mahkamah Agung Tahun 2016 Sebagai Pedoman Pelaksanaan Tugas Bagi Pengadilan.
}

mengadili OOD pasca berlakunya UUAP adalah disebabkan UUAP sendiri. UUAP membuka perluasan kewenangan Peratun namun UUAP tidak secara spesifik, sistematis dan memadai mengatur peralihan yuridiksi peradilan umum dalam perkara OOD kepada yuridiksi Peratun dalam perkara-perkara menyangkut tindakan administrasi pemerintahan. UUAP tidak menjelaskan sama sekali makna frasa "penetapan tertulis yang mencakup tindakan faktual" vide Pasal 87 huruf (a) UUAP.

\section{a. Problematik Pengertian Tindakan Faktual}

Ketiadaan penjelasan tentang frasa "penetapan tertulis yang mencakup tindakan faktual" vide Pasal 87 huruf (a) UUAP menimbulkan pertanyaan tentang persamaan atau perbedaan secara yuridis dari karakteristik tindakan faktual dengan pengertian tindakan hukum publik tidak tertulis (unwritten public law juridical acts atau ongeschreven publiekrechtelijke rechtshandelingen-lawan katanya adalah written public law juridical acts $=$ decisions (geschreven publiekrechtelijke rechtshandelingen $=$ besluiten) yang terdiri dari individual decision dan decisions with a general application (besluiten van algemene strekking). Sebelum berlaku UUAP pun telah terlihat keragamaan penafsiran terhadap pengertian tindakan faktual, keragaman tersebut tidak bisa dilepaskan dari kompleksitas sekaligus ambiguitas makna tindakan faktual, istilah ini sering diasosiasikan sebagai tindakan pemerintahan yang tidak mengandung konsekuensi yuridis namun dari beberapa ilustrasi kasus justru terdapat kontradiksi antara defenisi dengan contoh-contohnya. Philiphus M. Hadjon ${ }^{31}$ mensejajarkan istilah tindakan faktual (feitelijke handeling) dengan perbuatan materil; Kuntjoro Purbopranoto ${ }^{32}$ menyebutnya "tindakan pemerintahan yang

31 Hadjon, Philipus M. Hadjon, et al, Pengantar Hukum Administrasi Indonesia (Introduction to the Indonesian Administrative Law), Cet-1, Yogyakarta: Gajah Mada University Press, 1993, h. 176

32 Ibid. 
berdasarkan fakta"; Djenal Hoesen Koesoemahatmadja $^{33}$ menggunakan istilah "tindakan bukan yang tindakan hukum". Meskipun tindakan faktual secara teoritis dikategorikan sebagai bukan tindakan hukum namun dalam praktik tidak mudah mengatakannya tidak termasuk sebagai tindakan hukum.

Sehubungan dengan hal tersebut, P De Haan, sebagaimana dikutip oleh Prof. Philiphus M. Hadjon ${ }^{34}$ mengemukakan bahwa tindakan nyata tidak melahirkan akibat hukum (rechtgevolg) dari perbuatan pemerintah sedangkan tindakan hukum (rechthandelings) dimaksudkan untuk melahirkan akibat hukum. Dan memang mengacu kepada klasifikasi instrumen pemerintahan di Belanda seperti yang dibuat oleh Rene Seerden \& Frits Stroink ${ }^{35}$ tampak bahwa tindakan faktual (feitelijke handeling) bukan bagian dari instrumen pemerintahan, bukan bagian dari tindakan hukum pemerintah (rechthandelings). Pengertian tindakan faktual dalam literatur hukum administrasi Jerman sebagaimana dipaparkan oleh Meinhard Schröder ${ }^{36}$, mengandung arti sebagai tindakan mandiri (realakt/schlichte verwaltungshandeln; real act or simple sovereign action), artinya tindakan mandiri adalah tindakan yang bukan menjadi bagian langsung dari skema instrumen hukum pemerintahan, sekalipun demikian tindakan mandiri harus dipahami sebagai bagian inheren dari implementasi wewenang hukum publik.

Lebih lanjut Meinhard Schröder menyebutkan meskipun tindakan faktual dipahami sebagai tindakan non hukum namun tetapi tindakan faktual tersebut harus memperhatikan kesesuaiannya dengan hukum, sehingga apabila tindakan faktual membawa kerugian bagi pihak tertentu, sebagaimana halnya jika terjadi dalam

\footnotetext{
33 Ibid.

$34 \quad$ Ibid, h. 78.

35 René Seerden \& Frits Stroink, Administrative Law of the European Union, its Member States and the United States, A Comprative Analysis, Intersentia, Antwerpen-Oxford, 2007, h. 162-172

$36 \quad$ Ibid. h. 109
}

tindakan administrasi, maka pertanggungjawaban hukum berupa gugatan ganti rugi tidak bisa dilepaskan dari pelaku tindakan faktual tersebut. Memang dalam literatur hukum administrasi sendiri tidak mudah menentukan batas yang tegas antara kategori tindakan faktual dengan tindakan administrasi. Sebagai pedoman kiranya dapat disepakati bahwa tindakan administratif selalu berada di dalam wilayah hukum publik atau yang melaksanakan fungsi-fungsi yang dialokasikan ke hukum publik. Tindakan administrasi misalnya tindakan riil publik berupa pemberian penjelasan (explanatory act-Willenserklarungen), termasuk pemaparan informasi, peringatan publik, pelaporan, susunan atau opini para ahli. Tindakan yang memiliki fungsi faktual (Verrichtungen), misalnya pembayaran uang, patroli polisi, atau perjalanan menggunakan kendaraan dinas ${ }^{37}$.

Kekeliruan Pasal 87 huruf (a) UUAP adalah menyamakan tindakan hukum hukum administrasi (bestuurhandeling, administrative action) dengan tindakan non hukum (feitelijke handelingen, non-legal act) penetapan tertulis meliputi tindakan faktual, mungkin maksud pembuat undang-undang merujuk pengertian tindakan tidak tertulis berdasarkan hukum publik (unwritten public law juridical acts; ongeschreven publiekrechtelijke rechtshandelingen) yang maknanya lebih dekat dengan pengertian tindakan administrasi pemerintahan yakni perbuatan pejabat pemerintahan atau penyelenggara negara lainnya untuk melakukan dan/atau tidak melakukan perbuatan konkret dalam rangka penyelenggaraan pemerintahan ${ }^{38}$.

\section{b. Rekonstruksi Makna}

Ruang lingkup kewenangan Peratun mengadili pekara-perkara yang masuk dalam

\footnotetext{
$37 \quad$ Ibid. h.116.

38 UU Administrasi Pemerintahan. Ps. 1 angka (8). Dalam literatur common law, administrative action didefenisikan sebagai: "the acts of administrative agencies, covering any of their administrative, judicial or (limited) legislative functions". Neil Hawke \& Neil Parpworth, Op. Cit., h. xlv.
} 
kategori OOD akan lebih mudah dipahami jika pengertian tindakan faktual merupakan bagian dari tindakan administrasi pemerintahan, tidak perlu dilihat secara dikotomis pengertian tindakan administrasi dengan tindakan faktual. Alasannya adalah dari rumusan ketentuan Pasal 75 dan 76 UUAP pada pokoknya mengandung gagasan bahwa warga masyarakat yang dirugikan terhadap keputusan dan/atau tindakan dapat mengajukan upaya administratif kepada pejabat pemerintahan atau atasan pejabat yang menetapkan dan/atau melakukan keputusan dan/atau tindakan. Upaya administratif terdiri atas: keberatan dan banding ${ }^{39}$. Badan dan/atau Pejabat Pemerintahan berwenang menyelesaikan keberatan atas keputusan dan/atau tindakan yang ditetapkan dan/atau dilakukan yang diajukan oleh warga masyarakat. Dalam hal warga masyarakat tidak menerima atas penyelesaian keberatan oleh badan dan/atau pejabat pemerintahan, warga masyarakat dapat mengajukan banding kepada atasan pejabat. Dalam hal warga masyarakat tidak menerima atas penyelesaian banding oleh atasan pejabat, warga masyarakat dapat mengajukan gugatan ke Pengadilan. Pengadilan yang dimaksud adalah PTUN ${ }^{40}$. Artinya terlepas ketentuan Pasal 87 huruf (a) UUAP yang menggunakan istilah "tindakan faktual", namun konstruksi ketentuan Pasal 75 dan 76 UUAP dikaitkan dengan Pasal 1 angka 18 UUAP memberikan dasar kepada Peratun mengadili objek sengketa di luar keputusan tertulis yakni tindakan administrasi. Dengan demikian istilah "tindakan faktual" dalam ketentuan Pasal 87 huruf (a) UUAP seyogianya dibaca sebagai "tindakan administrasi" sebagai padanan dari istilah administratitieve rechtshandeling ${ }^{41}$, pembacaan seperti ini selain akan konsisten dengan Pasal 75 dan 76 UUAP, juga akan sejalan dengan tujuan dari UUAP sendiri yang salah satunya merevitalisasi eksistensi Peratun.

39 Undang-Undang Administrasi Pemerintahan, Ps. 75 ayat (1)

40 UU Administrasi Pemerintahan. Ps. 1 angka (18).
Jika pemaknaan Pasal 87 huruf (a) UUAP tidak dikaitkan dengan Pasal-Pasal sebelumnya maka esensi UUAP untuk merevitalisi Peratun tidak akan tersingkap, sebab istilah tindakan faktual dalam kajian hukum administrasi tidak memiliki signifikansi dibandingkan konsep tindakan administrasi yang mencakup pengertian tindakan hukum publik diluar pembuatan keputusan tertulis. Intinya, tindakan administrasi dapat terkait atau tidak terkait dengan pelaksanaan keputusan administrasi. Barangkali salah satu penjelasan mengapa dalam pandangan klasik, tindakan faktual dipahami sebagai tindakan biasa atau sebagai tindakan non-hukum (non legal-act) adalah persfektif hukum administratif yang senantiasa berhubungan dengan surat, beorientasi keputusan tertulis (schriftelijke beslissingen, written decision). Sebagaimana sudah disinggung sebelumnya di awal, kini kewenangan Peratun mengadili tindakan administrasi membawa Peratun Indonesia mendekati model Peradilan Administrasi di Prancis, dengan dua kewenangan utama yakni dalam recours objectif dan subjectif recours. Disamping itu, maksud dan tujuan dari kehadiran UUAP adalah sebaagi perisai perlindungan hukum administrasi bagi pemerintah dan penduduk. Pengadilan dituntut lebih berkeadilan menjembatani berbagai persinggungan hubungan pemerintah dan penduduk yang terkadang tidak sejalan tapi selamanya selalu berpasangan dalam entitas kebangsaan dan/atau kenegaraan. Tantangan perubahan yang akan dihadapi Peratun sangat radikal dan fundamental, semua stakeholder terkait perlu memberikan perhatian yang intens dan konstruktif.

Terlepas dari segala kontroversi Pasal 87 huruf (a) UUAP dikaitkan dengan SEMA No. 4/2016 tersebut di atas, hukum administrasi Indonesia kontemporer kini dihadapkan kepada berbagai pertanyaan fundamental menyangkut konsepsi tanggung-jawab administrasi (administrative liability) dan

41 Indroharto. Usaha Memahami Undang-Undang Tentang Peradilan Tata Usaha Negara, Buku I, Jakarta: Pustaka Sinar Harapan, 2000, h. 146-147 
perlindungan hukum atas tindakan administrasi pemerintahan (law protection upon administrative action). Perluasan kewenangan absolut Peratun untuk mengadili tindakan administrasi pemerintahan (administrative torts), yang secara drastis mengurangi kewenangan hakim perdata dalam menerapkan pasal 1365 KUHPer, sebaiknya dilihat dari persfektif optimalisasi penguatan rezim hukum publik melakukan kontrol yuridis terhadap pemerintah. Penguatan rezim hukum publik dalam UUAP telah membawa babak baru hukum administrasi Indonesia dalam mewujudkan perlindungan hukum baik kepada warga maupun para administrasi. Oleh karena pengertian pasal 1365 KUHPer lebih bersifat sebagai asas hukum dibandingkan dengan rumusan normatif suatu aturan, maka dengan sendirinya tidak akan otomatis semua perkara yang potensial diajukan berdasarkan perkara OOD akan beralih secara total kepada Peratun. Ketentuan pasal 1365 KUHPer akan dapat tetap berlaku sepanjang tidak diatur tersendiri oleh peraturan hukum lain, sehingga ketentuan pasal 1365 KUHPer akan menjadi sarana hukum terakhir bagi masyarakat (ultimum remedium, the last ressort) untuk mempersoalkan perbuatan hukum pemerintah apabila sarana hukum berdasarkan ketentuan hukum administrasi telah habis digunakan. Dengan semakin menguatnya rezim hukum administrasi pasca keluarnya UUAP, Peratun merupakan lembaga hukum utama dalam mengadili perbuatan hukum pemerintah, peran peradilan umum akan lebih merupakan sebagai pelengkap sistem perlindungan hukum. Dalam jangka panjang perlu dikonsolidasikan kelembagaan hukum dan sistem yang menopang jalannya sistem duality of jurisdiction sebagai sarana perlindungan hukum masyarakat atas perbuatan melawan hukum pemerintah dalam persfektif administrative torts.

\section{Simpulan}

Kehadiran

UUAP memperluas kewenangan Peratun mengadili keputusan/tindakan pemerintah. Perluasan ini sangat progresif, melebihi proyeksi target perluasan kompetensi absolut Peratun. Namun demikian perluasan tersebut tidak secara serta merta mengalihkan secara total kewenangan hakim perdata, meski peluangnya menjadi sangat kecil kini, untuk menerapkan pasal 1365 KUHPer dalam dalam perkara-perkara yang selama ini dikenal sebagai perkara OOD. Dalam sudut pandang pemahaman seperti ini kiranya pemaknaan terhadap SEMA No. 4/2016, yang menegaskan kewenangan Peratun adalah termasuk mengadili perbuatan melanggar hukum oleh pemerintah dalam arti perkara OOD, harus secara lebih seksama diperhatikan dan diterapkan. Keterbatasan rumusan normatif pasal 1365 dalam beberapa hal justru sekaligus merupakan kelebihannya, rumusan tersebut akan selalu terbuka digunakan untuk menjerat perbuatanperbuatan hukum pemerintah yang merugikan warga masyarakat sepanjang tidak diatur secara khusus dan lebih spesifik oleh ketentuan lain di bidang hukum administrasi. Pada titik inilah dibutuhkan kebijakan hukum lebih lanjut dari Mahkamah Agung agar dapat mengatur secara lebih teknis peralihan yuridiksi Peradilan Umum ke Peratun dalam mengadili perkara OOD. Dalam hal ini, sangat diperlukan kerangka aturan sebagaimana pernah diatur dalam SEMA No. 1/1991 yang mengatur petunjuk teknis pelaksanaan UU 5/1986 Tentang Peratun dikaitkan dengan pasal 142 UU Peratun.

\section{DAFTAR PUSTAKA}

\section{A. Buku}

Erliyana, S., 2005, Keputusan Presiden: Analisis Keppres RI 1987-1998, Jakarta: Program Pascasarjana Fakultas Hukum Universitas Indonesia

Rosa, A., 2003, Perbuatan Melawan Hukum, Jakarta: Program Pasca Sarjana Fakultas Hukum Universitas Indonesia 
Manan, B., 2010, Menjaga Kemerdekaan Pers di Pusaran Hukum, Jakarta: Dewan Pers

Brown, L. Neville \& John S Bell, 1998, French Administrative Law, Fifth Edition, (Oxford: Oxford University Press

Ali, C., 1978, Yurisprudensi Indonesia Tentang Perbuatan Melawan Hukum oleh Penguasa, Bandung: Binacipta

Simanjuntak, E., 2014, Beberapa Anotasi Terhadap Pergeseran Kompetensi Absolut Peradilan Umum Kepada Peradilan Administrasi Pasca Pengesahan UU. No. 30 Tahun 2014 dalam Subur MS dkk (eds), Bunga Rampai Peradilan Administrasi Kontemporer, Yogyakarta: Genta Press

Hawke, Neil \& Neil Parpworth, 1995, Introduction To Administrative Law, London: Cavendish Publishing Limited

Hadjon, P.M., 1987, Perlindungan Hukum Bagi Rakyat di Indonesia; Sebuah Studi Tentang Prinsip-prinsipnya, Penerapannya oleh Pengadilan Dalam Lingkungan Peradilan Umum dan Pembentukan Peradilan Administrasi Negara, Surabaya: Bina Ilmu.

Hadjon, P.M., 1993, Pengantar Hukum Administrasi Indonesia (Introduction to the Indonesian Administrative Law), Cet-1, Yogyakarta: Gajah Mada University Press.

Indroharto, 2000, Usaha Memahami Undang-Undang Tentang Peradilan Tata Usaha Negara, Buku I, Jakarta: Pustaka Sinar Harapan

Kranenburg, 1973, Perkembangan Peradilan Tentang Pertanggungan-Jawan Negara, judul asli 'de ontwikkeling der reschtspraak betreffnde de staatsaansprakelijkheid', diterjemahkan ole R.H. Kasman Singodimejo dan Mohamad Saleh, Jakarta: Penerbit Permata

Konijnenbelt, W., 2013, The Coming of Age of Review of Administrative Action in the Netherlands, hlm. 48, dalam Comtois, S., \& de Graaf, K. J. (Eds.), On Judicial and Quasi-Judicial Independence, (Governance \& Recht; No. 7), Den Haag: Eleven International Publishing

Abdoellah, P., 2016, Revitalisasi Kewenangan PTUN, Gagasan Perluasan Kompetensi Peradilan Tata Usaha Negara, Yogyakarta: Cahaya Atma Pustaka.

Lotulung, P.E., 1993, Penegakan Hukum Lingkungan Oleh Hakim Perdata, Bandung: Citra Aditya Bhakti, 1993

Ridwan, 2009, Tiga Dimensi Hukum Administrasi Negara dan Peradilan Administrasi Negara, Yogyakarta: FH UII Press

Ridwan HR, 2011, Hukum Administrasi Negara, Jakarta: Rajawali Pers

Seerden, René \& Frits Stroink, 2007, Administrative Law of the European Union, its Member States and the United States, A Comprative Analysis, Intersentia, AntwerpenOxford

Stroink, F. \& E. van der Linden (Eds), 2005, Judicial Lawmaking and Administrative Law, AntwerpenOxford: Intersentia

Setiawan, 1989, Contoh-Contoh Kasus Perbuatan Melanggar Hukum Oleh Penguasa Perkembangannya Dalam Yurisprudensi di Negeri Belanda, dalam P.J.J. Sipayung (ed), Pejabat Sebagai Calon Tergugat dalam Peradilan Tata Usaha Negara, Buku Kedua, Jakarta: C.V. Sri Rahayu.

Boestomi, T. 1994, Hukum Perdata dan Hukum Tata Usaha Negara Dalam Teori dan Praktek, Bandung: Alumni

Yuke, T., 1997, Historical phases of State Liability as Law of Remedies-Some Introductory Remarks, dalam Yong Zhang (ed), Comperative Studies on Governmental Liability in East And Southeast Asia, Vol. 3, (The Hague/London/Boston: Kluwer Law International 


\section{B. Jurnal \& Internet}

Bressman, L. S., 2004, “Judicial Review of Agency Inaction: An Arbitrariness Approach", New York University Law Review, November

Barkhuysen, Tom. Willemien Ouden dan Ymre E. Schuurmans, 2012, "The Law on Administrative rocedures in the Netherlands", NALL, April-Juni, DOI:10.5553/NALL/.000005

Blachly, Frederick F., and Miriam E. Oatman. 1942, "Approaches to Governmental Liability in Tort: A Comparative Survey". Law and Contemporary Problems, vol. 9, no. 2, 1942, pp. 181-213. JSTOR, JSTOR, www.jstor.org/stable/1189497 Diaskes 14 Oktober 2017

Pugh, George W. Historical Approach to the Doctrine of Sovereign Immunity, 1953, 13 La. L. Rev. Available at: http://digitalcommons.law.lsu.edu/lal rev/vol13/iss3/5 Diakses 14 Oktober 2017

\section{Makalah, Artikel, Orasi Ilmiah dsb}

Yos Johan Utama, 2010, "Membangun Peradilan TUN yang Berwibawa", Disampaikan pada Upacara Penerimaan Jabatan Guru Besar Dalam Ilmu Hukum pada Fakultas Hukum Universitas Diponegoro Semarang, 4 Februari
Dani Elfah. "Keputusan dan Tindakan Administrasi Pemerintahan", Makalah Tidak Diterbitkan

\section{Dokumen Lain}

Naskah Akademik Rancangan Undang Undang Tentang Administrasi Pemerintahan, Kementerian Pendayagunaan Aparatur Negara dan Reformasi Birokrasi

SEMA No. 4 Tahun 2016 Tentang Pemberlakuan Rumusan Hasil Rapat Pleno Kamar Mahkamah Agung Tahun 2016 Sebagai Pedoman Pelaksanaan Tugas Bagi Pengadilan.

SEMA No. 1 Tahun 2017 Tentang Pemberlakuan Rumusan Hasil Rapat Pleno Kamar Mahkamah Agung Tahun 2017 Sebagai Pedoman Pelaksanaan Tugas Bagi Pengadilan

\section{E. Peraturan Perundang-Undangan}

Indonesia, Undang-Undang Tentang Perubahan Tentang Perubahan Kedua No. 5 Tahun 1986 Tentang Peradilan Tata Usaha Negara, UU. No. 51 Tahun 2009 (LNRI tahun 2009 No. 160, TLN No. 5079)

Indonesia, Undang-Undang Tentang Administrasi Pemerintahan, UndangUndang. No. 30 Tahun 2014 (LNRI tahun 2014 Nomor 292, TLN No. 5601). 